\title{
HUBUNGAN ANTARA PENGGUNAAN GOOGLE CLASSROOM DENGAN HASIL BELAJAR PENDIDIKAN PANCASILA DAN KEWARGANEGARAAN KELAS XI
}

\author{
Dhifa Putra Ramadhan, Susilaningsih, Arafah Husna \\ Jurusan Teknologi Pendidikan, Fakultas Ilmu Pendidikan, Universitas Negeri Malang \\ Jalan Semarang 5 Malang 65145 0341-574700 \\ dhifa.putra.1601216@students.um.ac.id
}

\section{Article History}

Received: 18 Juli 2020, Accepted: 14 Desember 2020, Published: 28 Mei 2021

\begin{abstract}
Abstrak
Penelitian ini bermaksud untuk menjelaskan adakah hubungan yang signifikan antara penggunaan Google Classroom dengan hasil belajar pebelajar kelas XI. Jenis penelitian ini ialah penelitian korelasional. Instrumen yang digunakan dalam penelitian ini adalah USE Questionnaries dan hasil penialaian akhir semester pada semester genap tahun ajaran 2019/2020. Sampel dalam penelitian ini adalah 80 orang yang ditentukan melalui teknik propotional random sampling dengan cara undian. Hasil analisis menunjukkan bahwa penggunaan Google Classroom memiliki hubungan yang signifikan dengan hasil belajar dan hubungan tersebut berjenis hubungan positif, artinya kenaikan pada nilai variabel penggunaan Google Classroom yang selalu disertai kenaikan nilai variabel hasil belajar, dan sebaliknya, turunnya nilai pada variabel Google Classroom selalu diikuti dengan turunnya nilai hasil belajar.
\end{abstract}

Keyword: Google Classroom; USE Questionnaries; Hasil Belajar

\begin{abstract}
This study intends to explain whether there is a significant relationship between the use of Google Classroom and the learning outcomes of class XI students This type of research is correlational research. The instruments used in this study were USE Questionnaries and the results of the final assessment of the semester in the even semester of the 2019/2020 school year. The sample in this study was 80 people who were determined through a proportional random sampling technique by lottery. The results of the analysis show that the use of Google Classroom has a significant relationship with learning outcomes and the relationship is of a positive type, meaning that an increase in the value of the Google Classroom usage variable is always accompanied by an increase in the value of the learning outcome variable, and vice versa, a decrease in the value of the Google Classroom variable is always followed by decrease in the value of learning outcomes.
\end{abstract}

Keyword: Put 3-5 your keywords here in Bahasa Indonesia; keywords separated by semicolon 


\section{PENDAHULUAN}

Pendidikan di era digital seperti sekarang menjadikan e-learning menjadi sebuah kebutuhan dalam kegiatan terkait pembelajaran. E-learning sendiri adalah salah satu contoh bahwa adanya perkembangan di dunia teknologi \& informasi. E-learning juga bisa dikatakan sebagai pembelajaran dalam jaringan atau daring dengan menggunakana internet (Yodha, Abidin, \& Adi, 2019). Sedangkan Mahmoud, Barakat, \& Ajjour (2016) menyat e-learning adalah sebuah sistem yang memungkinkan pemberian pembelajaran secara elektronik baik melalui internet atau perangkat lunak. Dari dua pendapat di atas dapat ditarik satu makna bahwa e-learning merupakan kegiatan belajar \& pembelajaran yang dilaksanakan dengan media elektronik atau suatu jaringan seperti internet.

Adanya inovasi pembelajaran melalui teknologi e-learning, dapat memberikan manfaat dari segi fleksibilitas waktu dan kemudahan dalam pengumpulan tugas dan pengungkapan pendapat. Namun banyak juga pebelajar yang menganggap metode konvensional (tatap muka) lebih baik daripada $e$ learning, karena menurut mereka lebih mudah memahami materi, serta lebih mudah juga melakukan interaksi dengan pendidik dengan bertatap muka (Cindy, Herlinda, \& Nuril, 2019). Walaupun begitu tingkat kebutuhan pendidikan berbasis daring maupun e-learning di Indonesia setiap tahunnya meningkat. Seperti data yang dihasilkan oleh squline pada bulan Agustus tahun 2017 menunjukkan bahwa Indonesia menduduki peringkat ke 8 dunia dengan pertumbuhan sebesar $25 \%$ pada industri pendidikan daring (Pangondian, Santosa, \& Nugroho, 2019).

Terutama dalam masa pandemi seperti ini yang mengharuskan untuk mengurangi aktivitas diluar rumah dan berinteraksi sosial secara tatap muka. Termasuk kegiatan pendidikan di semua jenjang, baik formal maupun informal terpaksa mengganti seluruh kegiatan belajar menjadi berbasis rumah masingmasing (Okmawati, 2020). Hal ini berdampak pada aplikasi atau software untuk membantu proses belajar dan pembelajaran daring menjadi meningkat penggunanya, salah satu platform pembelajaran yang populer pada masa pandemi seperti ini ialah Google Classroom atau yang biasa disebut $G$ Classroom (Tinungki \& Nurwahyu, 2020). G-Classroom ialah satu dari produk Google yang diluncurkan pada tahun 2014 (Ramadhani, Umam, Abdurrahman, \& Syazali, 2019). G-Classroom ialah layanan web gratis yang dikembangkan oleh Google untuk sekolah, yang bertujuan untuk menyederhan pembuatan, pendistribusian, dan penilaian tugas ataupun berbagi file pembelajaran, menjadi lebih efisien (Sukmawati \& Nensia, 2019). Selain efisiensi waktu, G-Classroom juga unggul dalam hal efisiensi biaya karena $G$-Classroom menggunakan sistem paperless yang artinya tidak menggunakan kertas selama proses pembelajaran berlangsung (Rahmad, dkk, 2019).

Berdasarkan data yang telah dikumpulkan sebelum penelitian, pada SMA Negeri 9 Malang, dapat diketahui bahwa penggunaan $G$-Classroom dalam pembelajaran daring belum terlaksana secara baik. Hal ini disebabkan oleh beberapa faktor, yaitu: banyak pebelajar merasa kesulitan untuk beradaptasi, dari yang sebelumnya pembelajaran dengan metode konvensional lalu berganti dengan daring, menggunakan G-Classroom, kemudian, banyak juga pebelajar yang tidak tepat waktu dalam pengumpulan tugas yang sudah diberikan, dan yang terakhir pebelajar dirasa kurang akftif, dalam menggunakan fitur-fitur yang tersedia dalam G-Classroom. Yang akhirnya, dari permasalahanpermasalahan tersebut mengakibatkan kecenderungan hasil belajar pebelajar menajadi menurun, dibanding saat pembelajaran secara konvesioanal.

Permasalahan-permasalahan di atas sebenarnya wajar terjadi saat menjalankan pembelajaran secara daring atau menggunakan e-learning, dikarnakan pembelajaran daring memiliki kelebihan \& kekurangan (Filippova, 2015). Untuk kelebihan dari pembelajaran secara daring antara lain: yang pertama, kemudahan akses terhadap informasi-informasi terkait pembelajaran, kemudian, pebelajar mendapatkan keleluasaan waktu dan tempat dalam menerima atau memberikan informasi-informasi terkait pembelajaran (Smedley, 2010) dan Penggunaan e-learning memungkinkan pengaturan kecepatan belajar, sesuai dengan kecepatan belajar pebelajar masing-masing (Arkorful \& Abaidoo, 2014). Namun 
terdapat pula beberapa kekurangan dari pembelajaran secara daring seperti kurangnya komunikasi langsung atau face to face antara pebelajar dengan pendidik, kondisi individu yang tidak dapat diperhatikan jauh lebih dalam, saat pembelajaran secara daring, kurangnya akses secara langsung pada sumber materi yang diajarkan, serta membutuhkan akses internet dan perangkat pendukung lainya, misalnya laptop atau smartphone.

Penelitian sebelumnya yang sudah dilakukan oleh Susanti (2016) mendapatkan hasil penelitian bahwa terdapat hubungan yang signifikan antara penggunaan $G$-Classroom terhadap hasil belajar kognitif pada mata pelajaran Biologi di SMA CHARIS Malang sebesar -0.328. Penelitian lainya mengenai $G$-Classroom yang dilakukan oleh Ashadi \& Suhaeb (2020) dengan menunjukan hasil analisis data sebesar 0.569 , yang artinya bahwa hubungan antara pemanfaatan $G$-Classroom dengan hasil belajar mahasiswa, memiliki hubungan yang signifikan.

Perbedaan penelitian terdahulu dengan penelitian ini, terletak pada fokus penelitian, variabel penelitian, subjek, mata pelajaran yang diteliti dan lokasi penelitian. Fokus pada penelitian ini adalah membahas tentang hubungan antara penggunaan G-Classroom terhadap hasil belajar pebelajar. Kemudian variabel yang diteliti pada penelitian ini terbagi menjadi dua yaitu variabel bebas dan variabel terikat. Variabel bebas dalam penelitian ini adalah penggunaan $G$-Classroom sedangkan variabel terikat adalah hasil belajar, untuk mata pelajaran pada penelitian ini adalah PPKn dan subyek beserta lokasi peneletiannya adalah pebelajar kelas XI. Berdasarkan paparan di atas, maka penelitian ini membahas mengenai hubungan antara penggunaan $G$-Classroom dengan hasil belajar pebelajar kelas XI

\section{METODE}

Penelitian ini memakai pendekatan kuantitatif, dengan jenis penelitiannya termasuk pada peneltian korelasional. Penelitian korelasional menurut Curtis, Comiskey, \& Dempsey (2016) memiliki tujuan untuk menentukan prevalensi dan hubungan antara variabel, serta untuk meramalkan peristiwa dari data dan pengetahuan terkini. Dengan menggunakan jenis penelitian korelasional, diharapkan dapat menjelaskan dengan baik bagaiamana hubungan antara penggunaan G-Classroom dengan hasil belajar pebelajar kelas XI. Variabel pertama atau variabel terikat pada penelitian ialah penggunaan GClassroom yang diukur menggunakan intsrumen USE Questionnaries, yang diciptakan oleh Lund (Asnawi, 2018).

USE Questionnaries merupakan singkatan dari Usefullnes (kegunaaan), Satisfaction (kepuasan), Ease Of Use (kemudahan). Pada faktor Ease of use dibagi menjadi 2 faktor, yaitu Ease of Learning (kemudahan belajar) dan Ease of Use (kemudahan penggunaan) (Kasih \& Delianti, 2020). Realibilitas USE Questionnaries mendapatkan alpha Cronbach's sebesar 0,98. Sedangkan validitas secara statistik dan praktis, menunjukan signifikan $\mathrm{r}$ antara 0,60 dan $0,82, \mathrm{p}<0,001$. Secara keseluruhan, USE Questionnaries merupakan instrumen yang valid dan dapat diandalkan, tetapi masih membutuhkan penyempurnaan lebih lanjut (Gao, Kortum, \& Oswald, 2018). Dalam penelitian ini responden menjawab setiap item USE Questionnaries dengan skala likert dengan empat tingkatan jawaban yaitu 'Sangat Setuju', yang kedua 'setuju', kemudian 'tidak setuju' dan yang terakhir 'sangat tidak setuju'. Kemudian kedua atau variabel bebas dalam penelitian ini adalah hasil belajar, yang diukur dengan menggunakan instrumen nilai PAS (Penialaian Akhir Semester) mata pelajaran PPKn pada semester genap tahun ajaran 2019/2020.

Populasi dalam penelitian ini adalah seluruh pebelajar kelas XI SMA Negeri 9 Malang pada tahun ajaran 2019/2020 yang seluruhnya berjumlah 337 pebelajar. Kemudian untuk sampel peneltian ditentukan dengan teknik proportional random sampling, dengan metode undian. Proportional random sampling, yaitu teknik pengambilan sampel yang dimana semua popuplasi mempunyai kesempatan yang sama untuk dijadikan sampel sesuai dengan proporsinya masing-masing, dengan memperhatikan 
pertimbangan unsur-unsur atau kategori di dalam populasi penelitian. (Sugiyono, 2016). Teknik ini dipilih agar sampel yang diambil, dapat menjangkau ke seluruh kelas yang ada.

Penentuan jumlah sampel dalam penelitian ini memakai rumus Slovin dengan tingkat error $10 \%$. Dari rumus tersebut didapatkan jumlah sampel sebesar 77,116 pebelajar, yang jumlahnya dibulatkan menjadi 80 pebelajar. Maka dari hasil tersebut, pada setiap kelas diambil 8 pebelajar. Untuk nama-nama yang menjadi sampel dalam penelitian ini diundi menggunakan bantuan situs wheelofnames.com. Berikut adalah langkah-langkah dalam pengambilan sampel, yang dilakukan: Melihat daftar absen yang ada dalam seluruh populasi, yang berjumlah 337 pebelajar, lalu, memasukan nama-nama pebelajar dari kelas XI BAHASA ke dalam situs wheelofnames.com untuk diundi secara acak. Setelah itu, muncul nama-nama pebelajar yang menjadi sampel penelitian dari kelas XI BAHASA. Kemudian, lakukan kembali langkah nomor 2 untuk setiap kelas lainya.

Analisis data penelitian dilakukan agar data yang sudah diperoleh dapat dibaca dan ditafsirkan. Sehingga dapat menjawab rumusan masalah dalam penelitian ini. Teknik analisis data yang dipakai dalam penelitian ini untuk menguji hubungan antara penggunaan G-Classroom dengan hasil belajar pebelajar kelas XI pada mata pelajaran PPKn adalah teknik korelasi product moment, dengan bantuan SPSS 24. Sedangkan untuk mengetahui suatu hubungan antar variabel, memiliki hubungan yang signifikan atau tidak, secara praktis dengan cara mengkonsultasikan $r$ hitung pada $r$ tabel product moment (Sugiyono, 2016). Apabila $\mathrm{r}$ hitung $<\mathrm{r}$ tabel, artinya hubungan tidak signifikan. Selanjutnya apabila $r$ hitung $>\mathrm{r}$ tabel, maka terjadi hubungan yang signifikan. Dengan taraf kesalahan yang digunakan dalam penelitian ini adalah $\alpha=0,05$.

\section{HASIL}

\section{HASIL \& PEMBAHASAN}

Berdasarkan hasil dari angket yang telah di sebarkan keseluruh sampel penelitian, untuk variabel penggunaan $G$-Classroom didapatkan data deskriptif statistik dengan bantuan program SPSS 24, untuk nilai tertinggi dari penilaian penggunaan $G$-Classroom sebasar 117,00 dan nilai terendah sebesar 72,00. Untuk rata-rata nilai USE Questionnaries dari 80 responden didapatkan nilai sebesar 94,8875. Serta median dan modus sebesar 91 dengan standar deviasi bernilaikan 11,244. Dengan hasil distibusi frekuensinya ditampilkan pada tabel 1 di bawah ini:

\section{Tabel 1. Kecenderungan Penggunaan Google Classroom}

\begin{tabular}{cccc}
\hline No & Interval & Frekuensi & Presentase \\
\hline 1 & $72,00-77,00$ & 3 & $3.75 \%$ \\
\hline 2 & $78,00-84,00$ & 7 & $8.75 \%$ \\
\hline 3 & $85,00-91,00$ & 31 & $38.75 \%$ \\
\hline 4 & $92,00-98,00$ & 10 & $12.5 \%$ \\
\hline 5 & $99,00-105,00$ & 12 & $15 \%$ \\
\hline 6 & $106,00-112,00$ & 8 & $10 \%$ \\
\hline 7 & $113,00-119,00$ & 9 & $11.25 \%$ \\
\hline
\end{tabular}

Berdasarkan tabel 1. Di ketahui frekuensi terbesar pada kelas interval 85,00 - 91,00 dengan jumlah frekuensi 31 responden (38,75\%). Sedangkan jumlah frekuensi terkecil pada kelas interval 72,00 - 77,00 dengan jumlah responden sebanyak $3(3,75 \%)$. Setelah diketahui nilai minimum (Xmin) dan nilai maximal (Xmax), maka menentukan kecenderungan variabel dengan mencari rata-rata ideal (Mi) dengan rumus $\mathrm{Mi}=1 / 2(\mathrm{Xmax}+\mathrm{Xmin})$ sehingga diperoleh $\mathrm{Mi}=1 / 2(117+72)=95$ dan mencari standar deviasi ideal (Sdi) dengan rumus SDi $=1 / 6$ (Xmax-Xmin) sehingga standar deviasi ideal menjadi 1/6 $(117-72)=8$. Dari perhitungan di atas dapat dikelompokan menjadi 3 kelas sebagai berikut: Baik $=X \geq$ 103, Cukup $=87 \leq X<103$, Kurang $=X<87$. Berdasarkan 3 kelompok tersebut, maka tabel distribusi kecenderungan penggunaan Google Classrom ditampilkan pada tabel 2 di bawah ini: 
Tabel 2. Kecenderungan Penggunaan Google Classroom

\begin{tabular}{ccccc}
\hline No & Interval & Frekuensi & Presentase & Kelompok \\
\hline 1 & $<87$ & 18 & $22,5 \%$ & Kurang \\
\hline 2 & $87-103$ & 43 & $53,75 \%$ & Cukup \\
\hline 3 & $>103$ & 19 & $23,75 \%$ & Baik \\
\hline
\end{tabular}

Dari tabel 2. menunjukkan bahwa penggunaan G-Classroom pada mata pelajaran PPKn pada kelompok 'kurang' sebanyak 18 responden (22,5\%), kelompok 'cukup' sebanyak 43 responden $(53,75 \%)$, dan pada kelompoki 'baik' sebanyak 19 responden $(23,75 \%)$. Dari hasil tersebut maka dapat disimpulkan bahwa mayoritas pebelajar beranggapan penggunaan $G$-Classroom dalam pembelajaran PPKn pada kelompok cukup dan dapat dimaknai penggunaan G-Classroom dalam pembelajaran PPKn, berbanding lurus dengan skor yang didapatkan. Apabila semakin tinggi skor yang didapatkan, maka penggunaan $G$-Classroom semakin tinggi. Begitu juga sebaliknya, apabila skor yang didapatkan semakin rendah maka dapat dikat penggunaan $G$-Classroom semakin rendah.

Sedangkan untuk data deskriptif variabel hasil belajar pebelajar dari nilai PAS (Penilaian Akhir Semester mata pelajaran PPKn pada semester genap tahun ajaran 2019/2020, didapatkan nilai tertinggi dari penilaian akhir semester pebelajar pada mata pelajaran PPKn, sebasar 97,00 dan nilai terendah sebesar 57,00. Untuk rata-rata hasil belajar pebelajar dari 80 sampel yang terpilih didapatkan nilai sebesar 82,10. Serta median sebesar 83,00 dan modus sebesar 87,00 dengan standar deviasi bernilaikan 7,38. Kemudian untuk hasil distibusi frekuensi dari variabel hasil belajar, ditampilkan ditampilkan pada tabel 3 di bawah ini:

Tabel 3. Kecendrungan Penggunaan Google Classroom

\begin{tabular}{cccc}
\hline No & Interval & Frekuensi & Presentase \\
\hline 1 & $57,00-61,00$ & 2 & $2.5 \%$ \\
\hline 2 & $62,00-67,00$ & 2 & $2.5 \%$ \\
\hline 3 & $68,00-73,00$ & 6 & $7.5 \%$ \\
\hline 4 & $74,00-79,00$ & 14 & $17.5 \%$ \\
\hline 5 & $80,00-85,00$ & 25 & $31.25 \%$ \\
\hline 6 & $86,00-91,00$ & 26 & $32.5 \%$ \\
\hline 7 & $92,00-97,00$ & 5 & $6.25 \%$ \\
\hline
\end{tabular}

Berdasarkan tabel 3. Diketahui bahwa jumlah frekuensi terbanyak pada rentang nilai 86.00 91.00 dengan jumlah 26 pebelajar dari total 80 pebelajar yang menjadi sampel, kemudian frekuensi terkecil pada rentang nilai $57.00-61.00$ dan rentang nilai $62.00-67.00$ dengan masing-masing 2 pebelajar, pada setiap rentang nilainya. Setelah diketahui nilai minimum (Xmin) dan nilai maximal (Xmax), maka menentukan kecenderungan variabel dengan mencari rata-rata ideal (Mi) dengan rumus $\mathrm{Mi}=1 / 2(\mathrm{Xmax}+\mathrm{Xmin})$ sehingga diperoleh $\mathrm{Mi}=1 / 2(97+57)=77$ dan mencari standar deviasi ideal (Sdi) dengan rumus $\mathrm{SDi}=1 / 6$ (Xmax-Xmin) sehingga standar deviasi ideal menjadi 1/6 (117-72) = 6,67 yang dibulatkan menjadi 7. Dari perhitungan di atas dapat dikelompokan dalam 3 kelas sebagai berikut: Baik $=\mathrm{X} \geq 84$, Cukup $=70 \leq \mathrm{X}<84$, Kurang $=\mathrm{X}<70$. Berdasarkan 3 kelompok tersebut, maka tabel distribusi kecenderungan hasil belajar ditampilkan pada tabel 4 di bawah ini:

Tabel 4. Kecenderungan Hasil Belajar

\begin{tabular}{ccccc}
\hline No & Interval & Frekuensi & Presentase & Kelompok \\
\hline 1 & $<70$ & 4 & $5 \%$ & Kurang \\
\hline 2 & $70-84$ & 45 & $56.25 \%$ & Cukup \\
\hline 3 & $>84$ & 31 & $38.75 \%$ & Baik \\
\hline & Total & 80 & $100 \%$ & \\
\hline
\end{tabular}


Berdasarkan tabel 4. menunjukkan bahwa hasil belajar pada mata pelajaran PPKn pada kelompok 'kurang' sebanyak 4 responden atau hanya $5 \%$ dari total 80 responden,pada kelompok 'cukup' sebanyak 45 responden $(56.25 \%)$, dan pada kelompok 'baik' sebanyak 31 responden $(38,75 \%)$. Dari hasil tersebut maka dapat disimpulkan bahwa kecenderungan hasil belajar pebelajar pada mata pelajaran PPKn berada pada rentang nilai 70 - 84 atau termasuk kelompok 'cukup' dengan jumlah 45 pebelajar atau $56.25 \%$ dari jumlah keselurahan 80 pebelajar.

Hasil analisis data dengan uji product moment, yang dilakukan melalui program SPSS 24 didapatkan hasil seperti pada tabel 5 dibawah ini:

Tabel 5. Korelasi Pearson antara penggunaan Google Classroom dengan hasil belajar

\begin{tabular}{|c|c|c|c|}
\hline \multicolumn{4}{|c|}{ Correlations } \\
\hline & & Google Classroom & Hasil belajar \\
\hline \multirow[t]{3}{*}{ Google Classroom } & Pearson Correlation & 1 & $.393^{* *}$ \\
\hline & Sig. (2-tailed) & & .000 \\
\hline & $\mathrm{N}$ & 80 & 80 \\
\hline \multirow[t]{3}{*}{ Hasil Belajar } & Pearson Correlation & $.393^{* *}$ & 1 \\
\hline & Sig. (2-tailed) & .000 & \\
\hline & $\mathrm{N}$ & 80 & 80 \\
\hline
\end{tabular}

Diketahui dari tabel 5 diatas, untuk besaran koefesien korelasi Pearson adalah 0,393. Yang dimana hasil tersebut menunjukan bahwa hubungan antara variabel penggunaan $G$-Classroom dan hasil belajar termasuk dalam hubungan positif, dikaren koefisien korelasinya bernilai positif. Hubungan yang positif ini memiliki makna bahwa setiap kenaikan pada nilai variabel penggunaan $G$-Classroom selalu disertai kenaikan nilai variabel hasil belajar, dan sebaliknya, turunnya nilai pada variabel penggunaan G-Classroom selalu diikuti oleh turunnya nilai variabel hasil belajar. Selain itu juga, hasil tersebut menunjukan bahwa bahwa hubungan antara variabel penggunaan $G$-Classroom dan hasil belajar termasuk ke dalam kategori rendah, sesuai dengan interpretasi arti nilai $r$ yang dijabarkan (Arikunto, 2013) dalam tabel 6 berikut ini:

Tabel 6. Tingkat Korelasi

\begin{tabular}{cc}
\hline Koefisien Korelasi r & Kategori \\
\hline $0,91-1,00$ & Sangat Tinggi \\
\hline $0,71-0,90$ & Tinggi \\
\hline $0,41-0,70$ & Sedang \\
\hline $0,21-0,40$ & Rendah \\
\hline $0,00-0,20$ & Sangat Rendah \\
\hline
\end{tabular}

Diketahui hasil koefisien korelasi Pearson pada penelitian ini, menunjukan hasil 0.393. Dengan hasil tersebut, letak tingkat korelasi pada penelitian ini berada diantara 0,21 - 0,40 yang dimana menurut tabel 6, hasil tersebut termasuk pada kategori rendah. Maknanya, penggunaan G-Classroom termasuk ke dalam tingkat hubungan yang rendah dengan hasil belajar pebelajar. G-Classroom dalam penelitian ini memiliki makna sebagai media pembelajaran yang digunakan untuk membantu jalannya pembelajaran daring. Sadiman (2010) mengemukakan media pembelajaran yaitu semua hal yang dapat dimanfaatkan untuk menyampaikan pesan dari pengirim ke sang penerima. Dalam hal ini adalah proses membangkitkan pikiran, perasaan, perhatian, dan minat serta perhatian pebelajar sehingga proses belajar 
dapat berjalan. Selanjutnya, Sari, Soepriyanto, \& Wedi (2020) menjelaskan media pembelajaran alat penyalur informasi/pesan belajar yang digunakan untuk mengkondisikan seseorang saat belajar. Dari pernyataan tersebut dapat dimaknai bahwa media pembelajaran adalah alat yang digunakan oleh pendidik untuk menyampaikan pesan atau informasi dalam pembelajaran.

Tingkat hubungan yang rendah membuktikan bahwa hasil belajar tidak hanya berhubungan dengan media yang digunakan dalam pembelajaran, Tetapi terdapat faktor-faktor lain. Menurut Slameto (2010) terdapat 2 faktor utama yang berhubungan dengan hasil belajar. Yang pertama, Faktor intern. Faktor intern adalah faktor yang ada pada individu pebelajar. Faktor ini meliputi, jasmaniah (kesehatan, tinggi badan, berat badan, dan kondisi anggota badan) dan psikologis (intelegensi, kesukaan, bakat, kematangan dan kesiapan). Faktor yang kedua, adalah Faktor ekstern. Faktor ekstern merupakan faktor yang berasal di luar individu. Faktor ekstern terdiri dari, keluarga (pola asuh, hubungan antara anggota keluarga, suasana rumah, kondisi ekonomi, perhatian orang tua, dan latar belakang keluarga), Sekolah (media, metode mengajar, kurikulum, hubungan pendidik dengan pebelajar, hubungan antara pebelajar, peraturan sekolah, alat-alat pelajaran, waktu sekolah, standar pelajaran, keadaan lingkungan sekolah, dan tugas rumah), dan Masyarakat (kegiatan pebelajar bermasyarakat, media masa, teman bergaul, dan lingkungan sekitar).

Melihat dari banyaknya faktor yang berhubungan dengan hasil belajar dan hasil koefisien korelasi Pearson yang termasuk pada kategori rendah, sebaiknya Pendidik memperhatikan faktor-faktor lain yang dapat berhubungan dengan hasil belajar dan faktor yang berhubungan dengan kesuksesan dalam pembelajaran daring. Untuk menjadikan pembelajaran daring berjalan sukses maka terdapat 3 hal yang perlu diperhatikan. Yang pertama, teknologi. Pemilihan teknologi atau media yang digunakan harus dapat dijangkau oleh pebelajar dan memungkinkan untuk terjadinya pertukaran sinkronisasi dan asinkronisasi. Kemudian, karakteristik pendidik memiliki peran yang penting dalam untuk menjadikan pembelajaran secara daring berjalan secara efektif dan efisien. Karakteristik pendidik yang dapat memahami teknologi yang digunakanakan, dapat melakukan pendistibusian pembelajaran dengan baik, berdampak positif terhadap pembelajaran. Kemudian hal yang terakhir perlu diperhatikan adalah Karakteristik pebelajar. Pebelajar yang pintar serta memiliki disiplin serta rasa percaya diri yang tinggi mampu untuk melakukan pembelajaran dengan metode daring. Sedangkan pebelajar yang tidak memiliki keterampilan dasar dan disiplin diri tinggi maka lebih cenderung akan menyukai pembelajaran konvensional (Pangondian, Santosa, \& Nugroho, 2019).

Hasil ini juga mendukung hasil penelitian yang dilakukan oleh Yusuf, Bektiarso, \& Sudarti (2020) yang menunjukan hasil bahwa terdapat pengaruh yang siginifikan antara model pembelajaran dengan model PBL dan penggunaan media G-Classroom dengan aktivitas belajar dan hasil belajar. Kemudian hal senada juga ditunjukan dari hasil penelitian yang dilakukan Nirfayanti \& Nurbaeti (2019) yang menunjukan hasil bahwa terdapat pengaruh yang signifikan antara motivasi belajar mahasiswa dengan penerapan G-Classroom saat pembelajaran.

Berdasarkan hasil dari penelitian yang sudah dilakukan dan hasil penelitian terdahulu sebaiknya pemerintah dapat membuat suatu sistem e-learning untuk mendukung pembelajaran daring dengan berbagai fitur-fitur dan kelebihan dari G-Classroom, kelebihan yang pertama Goolge Classroom menggunakan sistem berbasis Cloud, dengan sistem ini memudahkan pengguna untuk berbagi dengan layanan-layanan Gooogle lainya (Youssef, 2012). Lalu, kelebihan berikutnya adalah Flexible, pengguna dapat mengakses G-Classroom dimana saja dan kapan saja dan yang terakhir Mobile Friendly, untuk mendukung fleksibilitas Google Classrom dirancang untuk dapat diakses pada perangkat mobile dengan baik (Iftakhar, 2016). E-learning yang dirancang pun juga harus menyesuaikan dengan karakter-karakter pendidik \& pebelajar di Indonesia. Karena menurut Esichaikul, Lamnoi, \& Bechter (2011) kebany $e$ learning yang ada saat ini masih belum bisa menjangkau berbagai macam karakter dari penggunanya, seperti motivasi belajar yang berbeda-beda, tingkat pengetahuan, gaya belajar serta kompetensi yang 
berbeda. Sehingga kelancaran penerapan pembelajaran dan keefektifan pembelajaran pun menjadi kurang optimal.

Selain itu juga bisa menambahkan fitur-fitur lain, yang tidak ada dalam G-Classroom. Seperti yang diungkapkan oleh Englishtina (2019) G-Classroom masih memiliki beberapa kekurangan, yang pertama, sulitnya manajemen akun, dalam G-Classroom tidak mengizinkan akses dari banyak domain. Bagi pengguna yang belum memiliki akun Gmail maka harus membuat terlebih dahulu, untuk dapat mengakses G-Classroom. Lalu, G-Classroom dirasa terlalu 'Google' untuk pengguna baru Google menemukan kesulitan dengan banyaknya simbol-simbol Google di dalamnya, karena ada beberapa tombol dengan ikon yang hanya diketahui oleh pengguna Google dan kemudian layanan-layanan pendukung di dalam G-Classroom juga semuanya serba Google. Kekurangan berikutnya, G-Classroom tidak memiliki kuis atau tes otomatis, kekurangan ini menjadikan salah satu alasan utama bahwa GClassroom belum dapat sepenuhnya menggantikan kelas konvensional adalah karena G-Classroom belum mampu memberikan kuis atau tes otomatis untuk pebelajar. Secara umum, G-Classroom lebih cocok untuk pengalaman blanded learning daripada pembelajaran yang sepenuhnya daring (Rabbi, Zakaria, \& Tonmoy (2018). Kekurangan yang terakhir, belum tersedianya fitur live chat, di GClassroom jika ingin berinteraksi antara pengguna, hanya bisa dilakukan dengan menggunakan fitur comment. Hal ini mengakibatkan interaksi antar pengguna secara personal belum bisa dilakukan.

\section{SIMPULAN}

Berdasarkan analisis data yang sudah dilakukan maka dapat dikat bahwa rumusan masalah dari penelitian ini terjawab, yaitu terdapat hubungan yang signifikan antara penggunaan $G$-Classroom dengan hasil belajar pebelajar kelas XI. Berdasarkan hasil yang telah didapatkan, maka saran yang diajukan adalah sebagai berikut, yang pertama pendidik diharapkan bisa memilih media pembelajaran yang tepat dalam proses belajar mengajar, karena itu menjadi salah satu faktor yang dapat membangkitkan keinginan, minat, motivasi dan memberikan rangsangan saat kegiatan belajar sampai dengan hasil belajarnya bahkan memberikan pengaruh-pengaruh psikologis terhadap pebelajar yang menggunakan media tersebut. Kemudian pebelajar diharapkan bisa meningkatkan kemandirian dan kemampuan beradaptasi yang cepat dengan media atau metode apapun yang digunakan. Di karenakan media ataupun metode yang digunakan dalam pembelajaran, merupakan salah satu faktor yang berhubungan dengan hasil belajar

DAFTAR RUJUKAN Arikunto. (2013). Prosedur Penelitian: Suatu Pendekatan Praktik. Jakarta: Rineka Cipta.

Arkorful, V., \& Abaidoo, N. (2014). The role of e-learning, the advantages and disadvantages of its adoption in. International Journal of Education and Research, 397-410.

Ashadi, N. R., \& Suhaeb, S. (2020). Hubungan Pemanfaatan Google Classroom Dan Kemandirian Terhadap Hasil Belajar Mahasiswa PTIK Pada Masa Pandemi. Jurnal Media Elektrik, Vol. 17 No. 2, 46-51.

Asnawi, N. (2018). Pengukuran Usability Aplikasi Google Classroom Sebagai E-learning Menggunakan USE Questionnaire (Studi Kasus: Prodi Sistem Informasi UNIPMA). RESEARCH: Computer, Information System \& Technology Management, 1(1), 17-21.

Cindy, C. A., Herlinda, M. K., \& Nuril, L. A. (2019). Perbandingan Efektifitas Proses Pembelajaran Menggunakan Metode E-Learning dan Konvensional. Literacy based Character and Professionalism Enhancement for Educators in Facing Industrial Revolution 4.0, 36-39.

Curtis, E. A., Comiskey, C., \& Dempsey, O. (2016). Importance and use of correlational research. Nurse researcher.

Englishtina, I. (2019). Using 'Google Classroom' App for Teaching Language. Big Data, Campus Automation, and Learner Management System Integration, 334-344. 
Esichaikul, V., Lamnoi, S., \& Bechter, C. (2011). Student Modelling in Adaptive E-Learning Systems. Knowledge Management \& E-Learning: An International Journal, 3(3), 342-355.

Filippova, T. (2015). Priority Fields of E-learning Development in Russia. Procedia - Social and Behavioral Sciences, 348-353.

Gao, M., Kortum, P., \& Oswald, F. (2018). Psychometric Evaluation of the USE (Usefulness, Satisfaction, and Ease of use) Questionnaire for Reliability and Validity. Proceeding of the Human Factors and Ergonomics Society Annual Meeting.

Iftakhar, S. (2016). Google Classroom: What Works And How?. Journal of Education and Social Sciences, 3, 12-18.

Kasih, A., \& Delianti, V. I. (2020). Analisis Usability Nagari Mobile Banking Menggunakan Metode Usability Testing dengan Use Questionnaire. VoteTEKNIKA: Jurnal Vocational Teknik Elektronika dan Informatika, 8(1), 125-131.

Mahmoud, A. Y., Barakat, M. S., \& Ajjour, M. J. (2016). Design and Development of ELearning. Journal of Multidisciplinary Engineering Science Studies, 498-504.

Nirfayanti, N., \& Nurbaeti, N. (2019). Pengaruh Media Pembelajaran Google Classroom Dalam Pembelajaran Analisis Real Terhadap Motivasi Belajar Mahasiswa. Proximal: Jurnal Penelitian Matematika, 2(1), 50-59.

Okmawati, M. (2020). The Use Of Google Classroom. Journal of English Language Teaching, 438443.

Pangondian, R. A., Santosa, P. I., \& Nugroho, E. (2019). Faktor - Faktor Yang Mempengaruhi Kesuksesan Pembelajaran Daring. Seminar Nasional Teknologi Komputer \& Sains (SAINTEKS), $1(1), 56-60$.

Rabbi, M. M. F., Zakaria, A., \& Tonmoy, M. M. (2018). Teaching Listening Skill through Google Classroom: A Study at Tertiary Level in Bangladesh. vol, 3, 2-7.

Rahmad, R., Wirda, M. A., Berutu, N., Lumbantoruan, W., \& Sintong, M. (2019, March). Google Classroom Implementation In Indonesian Higher Education. In Journal of Physics: Conference Series.

Ramadhani, R., Umam, R., Abdurrahman, A., \& Syazali, M. (2019). The Effect of Flipped-Problem Based Learning Model Integrated with LMS-Google Classroom for Senior High School Students. Journal for the Education of Gifted Young, 137-158.

Sadiman, A. (2010). Media Pendidikan Pengertian Pengembangan dan Pemanfaatanya. Jakarta: Rajawali Pers.

Sari, M. R., Soepriyanto, Y., \& Wedi, A. (2020). Digitalisasi Media Objek 3 Dimensi Kabel Fiber Opticberbantuan Piramida Hologram Untuk Sekolah Menengah Kejuruan. Jurnal Kajian Teknologi Pendidikan, 366-376.

Slameto. (2010). Belajar dan Faktor-Faktor yang Mempengaruhi. Jakarta: Rineka Cipta.

Smedley, J. (2010). Modelling the impact of knowledge management using technology. OR Insight, 233-250.

Sugiyono. (2016). Metode Penelitian Kuantitatif, Kualitatif dan R\&D. Bandung: PT. Alfabet.

Sukmawati, S., \& Nensia, N. (2019). The Role of Google Classroom in ELT. International Journal for Educational and Vocational Studies, 142-145. 
Susanti, L. (2016). Hubungan Penggunaan Google Classroom Sebagai Pembelajaran Efektif dan Paperless Terhadap Nilai Hasil Belajar Kognitif Pada Pelajaran Biologi di SMA Charis Malang. Prosiding Seminar Nasional Teknologi Pembelajaran dan Psikologi Pendidikan 2016.

Tinungki, G. M., \& Nurwahyu, B. (2020). The Implementation of Google Classroom as the E-Learning Platform for Teaching Non-Parametric Statistics during COVID19 Pandemic in Indonesia. International Journal of Advanced Science and Technology, 5793-5803.

Yodha, S. A., Abidin, Z., \& Adi, E. P. (2019). Persepsi Mahasiswa Terhadap Pelaksanaan E-Learning Dalam Mata Kuliah Manajemen Sistem Informasi Mahasiswa Jurusan Teknologi Pendidikan Universitas Negeri Malang. Jurnal Kajian Teknologi Pendidikan, 181-187.

Youssef, A. E. (2012). Exploring cloud computing services and applications. Journal of Emerging Trends in Computing and Information Sciences, 3(6), 838-847.

Yusuf, N. R., Bektiarso, S., \& Sudarti. (2020). Pengaruh Model PBL Dengan Media Google Classroom Terhadap Aktivitas Dan Hasil belajar Siswa. Jurnal Kajian Inovasi dan Aplikasi Pendidikan Fisika, 230-235. 